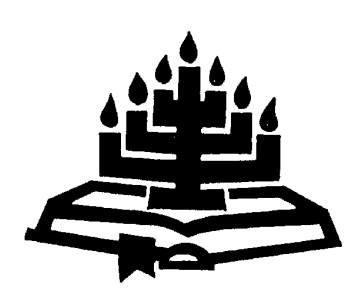

\title{
Die betekenis van die konsep land in die slot van die boek Amos
}

\author{
J.L. Helberg \\ Skool vir Bybelwetenskappe en Bybeltale \\ Potchefstroomse Universiteit vir CHO \\ POTCHEFSTROOM
}

\begin{abstract}
The meaning of the concept of land in the epilogue of the book of Amos

During the exilic and post-exilic eras the concept of land underwent a shift of meaning: land also acquired the meaning of city (and temple). If the epilogue of Amos is regarded as exilic or post-exilic, as most scholars think, one can expect that city rather than land shall be emphasized in the epilogue. The opposite, however, is true. This article tries to ascertain whether the concept "land" has a different place, value or meaning in the epilogue of Amos than in the rest of the book and whether this assumption casts any light on the relation between the different parts. The conclusion arrived at implies that the term used for land in the epilogue has a broader meaning than the traditional one attached to it by Israel. The epilogue makes a breakthrough to a universal approach pictured in eschatological colours but rooted in history. A correction is made to a "Zion-theology" and emphasis is laid on the land of the promise which is linked with the (true) covenantal relation with Yahweh implied in the terms "my people" and "your God". Whether dated as pre-exilic, exilix or post-exilic, the epilogue is in harmony with the essence of the rest of the book.
\end{abstract}

\section{Inleiding}

In die ballingskapse en na-ballingskapse tyd het daar in die verbondsvolk se benadering van die konsep land 'n betekenisverskuiwing plaasgevind. Land het ook stad en tempel ingesluit (Weinfeld, 1993:201). Die slot van die boek Amos word deur die meeste Ou-Testamentici beskou as van ballingskapse of naballingskapse oorsprong (vgl. vir 'n nadere bespreking van hierdie problematiek en tersaaklike literatuur daaroor, Helberg, 1997). Indien dit so is, kan 'n mens seker verwag dat die konsep van stad eerder as van land daarin 'n plek sal hê. 
Die teendeel is egter die geval. In hierdie artikel word die betekenis van land in die slot van Amos nagegaan en gekyk of land hierin 'n ander plek, waarde of betekenis het as in die res van die boek en of dit enige lig werp op die verhouding tussen die slot en die res van Amos.

Om die problematiek te beantwoord sal die betekenis van land en dié van stad in daardie tyd bekyk word asook die omstandighede wat verskuiwing in betekenis meegebring het. Teen hierdie agtergrond sal Amos 9:15 ondersoek word: "Ek sal my volk weer in hulle grond plant, en hulle sal nie weer uitgeruk word uit die grond wat Ek hulle gegee het nie, sê die Here jou God". Amos 9:15 sal benader word binne die verband van die voorspoedtyd wat hier in vooruitsig gestel word (9:13-14) en die opbou van die "vervalle hut van Dawid" (9:11-12).

Die onderwerp sal onder die volgende hoofde bespreek word: die plek en betekenis van land in die Ou Testament en in Amos; die plek en betekenis van stad in die Ou Testament en in Amos; die belofte van die opbou van die vervalle hut van Dawid; die buitengewoon voorspoedige tyd en die genieting van werksvrug; die optrede van Jahwe self om sy volk blywend in hulle grond te plant; samevatting en bevinding

\section{Die plek en betekenis van die land in die Ou Testament en in die boek Amos}

Uit die aard van die saak kan hier nie indringend op al die aspekte van die onderwerp ingegaan word nie (vgl. daarvoor Helberg, 1998). Ek beperk my hier tot die aspekte wat ons tema direk raak.

Die Ou-Testamentiese godsdiens is heel konkreet van aard. Landbesit en grondbesit val onder die seën van Jahwe. As historiese gewer van die land is Jahwe en nie Baäl nie, ook die gewer van vrugbaarheid (Gen. 27:27; 49:25-26; Deut. 28:3-5; 33:13-16; Jer. 5:24; Hos. 2:10-12). By volle burgerskap behoort besit van grond (Preuss, 1991:136).

Teenoor die land met sy vrugbaarheid staan die woestyn met sy onherbergsaamheid. Israel is na die uittog uit Egipte veertig jaar lank deur Jahwe in die woestyn versorg. Die woestyn het dus iets van 'n ambivalente betekenis. Die woestyntyd kan gesien word as ' $n$ tyd van 'n besondere verhouding met Jahwe. Daar het Israel trouens die Tora of wet ontvang wat so 'n wesenlike plek in hulle godsdiens ingeneem het om die wil van Jahwe te ken en daarvolgens te leef. Die woestyn is egter nie 'n ideale plek nie. Die terugkeer-na-diewoestynmotief kom dikwels by die profete voor. Hulle praat egter nie van terugkeer na die woestyn toe nie, maar van "soos die woestyn" gemaak te word. Dit slaan op algehele vernietiging en verlatenheid, op 'n verbondsvloek wat die 
einde van die gemeenskap in vooruitsig stel; nie die verandering van die omgewing nie (vgl. Frick, 1977:220; vgl. ook Talmon, 1984:682-685).

Cohn $(1981: 1,21)$ wys daarop dat nie verowering Israel se houvas op die land daarstel nie, maar die guns van Jahwe. Hy meen dat dit in die woestyn was waar die gedagte ontstaan het van "the deity as ultimate and personal, not subjected to the realm of divine fate, and that it is bound to Israel by covenant".

Ook die wet of Tora speel 'n belangrike rol in verband met die betekenis van die land. Israel is nie onmiddellik vanuit Egipte in die beloofde land ingelei nie. Eers vind die belangrike gebeurtenis van die wetgewing plaas. Die wet staan voorop. Die land is die plek waar daar volgens Jahwe se gebooie geleef moet word. Land bevat dus die verpligting van gehoorsaamheid as voorwaarde. Gottfriedsen (1985:160) sê dat daar tot in die laaste gedeeltes van die Ou Testament 'n verband gelê word tussen reën en gehoorsaamheid aan die Here. Hierdie stelling geld nie in absolute sin nie, want die voorwaarde rus ook weer in God se reddende optrede om Israel na Homself toe te bring (Eks. 19:4-6). 'n Uitdruklike verbandlegging ontbreek dan ook in die slot van Amos, hoewel dit inbegrepe is in die herstelde verhouding tussen Jahwe en sy volk (Kaiser, 1993: 23 wys daarop dat die boodskap van die Ou Testament wet én evangelie is en dat die vraag oor die geregtigheid van God sentraal staan).

By ander nasies in die tyd van Israel het 'n mitologiese benadering van wat gebeur en van wat bestaan, 'n sterk rol gespeel. 'n Sikliese tydsbenadering was aan die orde van die dag. Daarmee samehangend is die fokus gerig op heilige plekke waar seremoniële handelinge uitgevoer is om ' $n$ invloed op die verloop van gebeurtenisse uit te oefen. Die Ou-Testamentiese benadering daarenteen is nie mitologies nie, maar sterk histories van aard. Ou-Testamentiese skrywers het wel by mitologiese voorstellings aangesluit, want dit was handig om die kwaliteit van 'n plek na vore te bring in plaas van die lokaliteit. Tog was die Ou Testament se benadering van plek basies verskillend: ruimtelike werklikheid is verstaan in terme van 'n nuwe skepping wat nóg met die huidige wêreldorde nóg met niebestaan geïdentifiseer moet word. God is besig om in die geskiedenis 'n nuwe ruimtelike werklikheid teweeg te bring wat nie geskei is van die huidige wêreld van ruimte nie, maar wat verskil in kwaliteit. Die Ou-Testamentiese begrip van ruimte is nie mitologies nie, maar eskatologies. Dit kyk na die toekoms, nie na die verlede nie (Brinkman, 1992:47-48). Kaiser (1993:88) sê dat die denke van die $\mathrm{Ou}$ Testament ondanks die Deuteronomistiese rasionalisme van binne-mitiese aard is. Dit vertolk die metafore waarin dit van God se aard en van sy doen en late praat, as werklikheid. Mitiese denke verskil daarin van rasionele konsepte dat dit nie die eenheid van die wêreld konstrueer nie, maar dit aanvaar en in indiwiduele mites ' $n$ bepaalde antwoord op ' $n$ bepaalde vraag verstrek. 
Die fokus is in die Ou Testament gerig op God wat gebeurtenisse laat plaasvind. 'n Groot gedeelte van die Ou Testament is histories ingeklee, en Israel se belydenis is sterk gefokus op God se werksaamheid in hulle geskiedenis gesentreer (Deut. 26:5-11). Hieruit sou 'n mens kon aflei dat tyd vir God meer primêr is as ruimte of plek. Tog moet tyd en plek nie as teenstellings gesien word nie. Jahwe het Hom inderdaad nie so nou aan plekke verbind soos die geval was met ander nasies se gode nie. Hy tree wel vanaf plekke en lande op en is dus by mense en gebeurtenisse betrokke (Olivier, 1996:250), maar anders as by die ander nasies word Hy byvoorbeeld nie die God van 'n plek genoem nie (vgl. Baäl-Gasor, 2 Sam. 13:23 en Baäl-Hermon, Rigt. 3:3). Hy word egter net so min die God van tyd genoem. Feit is dat Hy nie die God van dinge genoem word nie, maar wel die God van mense ("die God van Abraham, Isak en Jakob", "die God van Israel”, Gen. 28:13; Eks 3:16; 2 Sam. 7:25-26). Daarmee word sy persoonlike aard benadruk. Die basiese verskil met die ander nasies lê dus op 'n ander vlak as bloot ' $n$ beskouing oor ruimte of tyd. Feit is verder dat ook in Israel se belydenis waarin geskiedenis so 'n oorwegende rol speel, die land 'n belangrike plek inneem.

Hierdie geskiedenis loop uit op die verkryging van die land (Deut. 26:9; vgl. Brinkman, 1992:26). In Jahwe se verbond met die aartsvaders speel die belofte van die land 'n wesenlike rol (Gen. 15; 17). Hoe belangrik die land egter ook al in Israel se bestaan en die verbondsbeloftes van Jahwe was, dit het nie 'n selfstandige betekenis gehad nie. Die land was altyd gebind aan die Goddelike belofte, of beter, aan God wat die belofte gegee het. Israel moes altyd onder die besef leef dat hulle nie inheems in die land is nie. Hulle is nie as volk in die land gebore nie. Hulle het nie van altyd af daar gewoon nie (Zimmerli, 1971:82). Dit is nie 'n skeppingsordening dat hulle daar is nie. Bowendien het die land vroeër aan ander nasies behoort. Hierdie nasies is deur Jahwe daar uitgedryf om plek te maak vir Israel wat die land bloot as 'n geskenk van Jahwe ontvang. Hy bly die eintlike besitter daarvan, nie die volk self of die koning of tempel nie (vgl. byvoorbeeld die bepalings insake die sabbatsjaar en hersteljaar, Lev. 25). Die volk is vreemdelinge en bywoners by Hom (Lev. 25:23; Ps. 39:13; 119:19).

Die land se betekenis lê daarin dat dit die plek is waar Jahwe woon, of nog beter gestel, waar Jahwe onder sy volk woon. Dit gaan vir Hom nie om die plek as sodanig nie - die hele wêreld behoort immers aan Hom - maar om sy verhouding met hulle en hulle s'n met Hom.

Eintlik is die land 'n simbool van die verlore tuin van Eden waar daar 'n besondere manier was waarop God en die mens met mekaar omgegaan het. Deur die mens se gebrek aan dankbaarheid, vertroue en gehoorsaamheid is die tuin hom egter deur God ontsê en het hy 'n vreemdeling geword, iemand sonder burgerregte. By Babel het die mensdom nog verder hul rug op God gekeer en nog verder van Hom vervreem geraak. Dan maak God egter 'n nuwe begin deur 
middel van een mens en die verhouding tussen hom en God: God roep Abraham uit sy omgewing, laat hom breek met dit wat strydig is met die diens van die ware God en beloof aan hom en sy nageslag 'n land. Met hierdie woonplek sal hulle die rus vind wat God vir die mens by die skepping bedoel het, veral 'n rus wat bestaan in vrede met God (Eks. 19:4). Ook deur die uittog uit Egipte het God vir Israel rus in vooruitsig gestel (Deut. 12:9-12).

God se roeping van Abraham is 'n nuwe begin; Hy roep vir Hom 'n eie, besondere volk vanuit die mensdom. Tog impliseer dit nie 'n absolute breuk tussen God en die res van die mensdom nie, maar Hy beloof aan Abraham dat al die nasies in hom geseën sal word (Gen. 12:2-3). Die roeping van Abraham en die geskiedenis van God met die volk Israel het 'n diepere doel as net hulleself en hulle stoflike en geestelike behoefte; 'n dieper doel ook as hulle land.

Abraham en die ander aartsvaders is eers vreemdelinge in die beloofde land (Gen. 19:9; 23:4). Tog is hulle nie bejammerenswaardig nie, want hulle leef uit die belofte van God. Bowendien is die verhouding met God self die belangrike waarom dit gaan ("Julle het gesien wat Ek aan Egipte gedoen het, en hoe Ek julle soos op arendsvlerke veilig gedra en na My toe gebring het" - Eks. 19:4). Die land is ' $n$ middel daarvoor. Wanneer hulle uiteindelik die land besit, sal hulle dit tog ook weer kan verloor as hulle verhouding met God nie reg is nie, net soos die Kanaäniete en ander nasies die land verloor het. Die profete waarsku daarteen en die profeet Amos sê dat ballingskap vir die Tienstammeryk onafwendbaar aan die kom is weens hulle sonde en onbekeerlikheid.

Toe Israel die land inderdaad verloor het, wou hulle tog nog vashou aan die beloftes van God aan die voorvaders. Toe moes hulle, volgens sommige teoloë, die beloftes egter voorwaardelik beskou weens die verlies van die land. Daarom is die gawe van die land op daardie stadium voorwaardelik gesien en is die onderhouding van die wet beskou as voorwaarde om die land binne te gaan. Dit is veral die Deuteronomistiese benadering (Deut. 6:17; Jer. 11:6; 31:33; Deut. 6:17 - vgl. Noort, 1995:137; Weinfeld, 1993:xxi). Hierteenoor word in die slot van Amos egter benadruk dat die redding vir die volk en hulle terugkeer na die land toe deur en deur die gevolg van Jahwe se eie inisiatief en optrede sal wees.

Die verlies van die land en die gepaardgaande ballingskap het die volk van Jahwe in 'n groot geloofskrisis gedompel. Volgens Hanson (1987:490) is dit nie toevallig dat die literatuur van die vroeë na-ballingskapse tyd dikwels oor die tema van chaos en skepping handel nie. Die verontrustende vraag dring hom nou aan die verbondsvolk op wie eintlik die lot van die Joodse volk bepaal. Hulle bevind hulle immers in die land waar nie Jahwe aanbid word as die hoogste regeerder oor die wêreld nie, maar Marduk. Hierdie kenmerkende probleem van die ballingskapse tyd kom egter nie in die slot van Amos voor nie. 'n Mens sou wel kon sê dat die probleem in dié sin gehanteer word dat 'n paradystoestand vir 
die toekoms in vooruitsig gestel word. Tog sluit hierdie gedeelte goed aan by Amos se verkondiging in die res van die boek dat Jahwe die absolute regeerder is. Dit is Hy wat die chaotiese toestand teweegbring in sy straf (9:1-4) wat vir Israel ontnugtering en ondergang bewerk omdat hulle vreemde gode vereer (5:1827).

Behalwe land het stad 'n belangrike rol in Israel se geskiedenis en denke gespeel.

\section{Die plek en betekenis van die stad in die Ou Testament en in Amos}

'n Stad het nie in die vroeë geskiedenis van Israel 'n belangrike positiewe rol gespeel nie, maar is eerder geassosieer met die plek waar die verhouding tussen God en die mensdom op 'n breuk uitgeloop het. In reaksie op die bou van die stad en toring van Babel het God vir Abraham geroep en nie vir hom 'n ander stad beloof nie, maar wel 'n land (Gen. 11:1-12:3).

Ook God se belangrike selfopenbaring aan Moses, waar Hy Homself as Jahwe bekend stel, vind nie in 'n stad plaas nie. Wanneer Hy ná die uittog uit Egipte sy wet aan sy volk gee, is dit ewe-eens nie in 'n stad nie, maar by Sinai. Levenson (1985:21) wys daarop dat Jahwe se selfbekendstelling in afgeleë plekke plaasvind, eerder as in die gevestigde en vasgestelde kultus van die stad. Selfs Jahwe se wyse van manifestasie reflekteer die onkontroleerbare en onvoorspelbare aard van die woestyn.

Eers ná die vestiging in die beloofde land het 'n stad vir Israel werklik 'n positief belangrike betekenis verkry. Dawid se roemryke oorwinning oor Jerusalem het aan hierdie stad in besonder ' $n$ belangrike betekenis besorg. Hierdie gebeurtenis het Dawid gered uit die groot probleem van die ongemaklike verhouding waarin die stam van Juda en die ander stamme tot mekaar gestaan het. Dawid hoef nou nie 'n hoofstad te kies wat enige van die twee kante afgeskeep sou laat voel nie. Hierdie stad was nie deel van enige van hulle se gebied nie en was sentraal geleë, heel geskik vir die administrasie van die ryk. Daarby het Dawid die uittog uit Egipte en alles wat godsdienstig daarmee saamhang, aan die stad Jerusalem verbind deur die verbondsark daarheen te bring (2 Sam. 6). Jerusalem se betekenis in die Bybelse godsdiens is dan ook baie sterk deur sy verbinding met Dawid bepaal, soos blyk uit die voorkoms van die uitdrukking "stad van Dawid" wat dikwels voorkom (2 Sam. 5:7, 9; 6:10, 12, 16; ens.). Tog is die gedagte van Jerusalem as stad van God meer oorheersend (Tsevat, 1982:934).

Die besondere betekenis van die stad Jerusalem word deur Cohn (1981:38) soos volg gestel: As die woning van die ewige God is Sionsberg self ewig. Daarom reflekteer die Psalms nie die historiese verlede toe Dawid die stad in besit geneem het nie, maar die ewige hede waarin Jahwe vanaf Sionsberg regeer (Ps. 
$46: 5 ; 76: 2 ; 122 ; 125: 1-2)$. In die slot van Amos is die fokus egter nóg op Sion self nóg op sy historiese band met Dawid, maar op die verhouding met Jahwe self in die land.

Dit is belangrik dat Jerusalem soms wel as manifestasie van Eden geteken word, maar dat daar nooit ' $n$ eenvoudige identifisering van die twee is nie. Sion is gevul met nuwe elemente wat nie in die Voortyd (Urzeit) teenwoordig is nie (Brinkman, 1992:27).

Levenson (1985:21, 23, 75, 138-140, 144, 145, 188) maak die volgende stellings wat vir ons onderwerp belangrik is: Die plek waar God sy wet aan Israel gee, is Sinai/Horeb, in niemandsland. Dit gebeur tussen die uittog uit Egipte en die intog in Kanaän. Die berg waar God Hom openbaar, is nóg onder Egiptiese nóg onder Kanaänitiese heerskappy, maar daar waar God heerskappy uitoefen. Die woestyn is ' $n$ simbool van vryheid en die berg 'n baken van bevryding van slawerny, van 'n totaal nuwe verhouding tussen volk en staat. Hier soos altyd word die Tora verbind met Moses, die nederige bemiddelaar van die verbond, nie met Dawid, die stigter van die dinastieke staat nie. Israel was 'n "koninkryk van priesters en 'n heilige volk" voordat hulle 'n volk van meer aardse aard geword het. Sinai speel geen praktiese rol in Israel se geskiedenis nie, maar het alleen 'n plek in die herinnering aan die Tora. Nie 'n mens se lokaliteit bepaal jou verhouding met God nie, maar jou gewilligheid om Hom in waarheid aan te roep (vgl. ook Ps. 145:18). Die tempel is nie 'n plek in die wêreld nie, maar die wêreld in kern. Daarom praat die Ou Testament van die hemelse en aardse teenwoordigheid van God sonder enige spanning tussen die twee (Ps. 11:4). Jerusalem is die aardse manifestasie van die hemelse tempel van God wat bo lokalisering verhewe is en die tempel op Sion is die aardse antitipe van die kosmiese argetipe. Mettinger (1982:37) sê dat die tempel die plek is waar die kategorie van ruimte getransendeer word en die grenslyn tussen hemel en aarde uitgewis word

Die skepping van die wêreld en die oprigting van die tempel is parallel. Daarom loop albei uit op rus (Ps. 132:13-14; Jes. 66:1). Die wêreld is God se tempel. Daarin vind Hy rus, soos in die miniatuur wat die mens daarvan maak, naamlik die tempel op die top van Sion. God is voortdurend by Jerusalem beskikbaar, nie by Sinai nie. Deur die gedagte van die eintlike Tora tot die Pentateug te beperk, is egter verseker dat die erfgenaam altyd ondergeskik sou wees aan die erflater, Sion aan Sinai, Dawid aan Moses (vgl. Deut. 34:10). Hierdie samestelling van die kanon spreek ook meer direk tot 'n Israel in beweging, met sy beloftes van land en rus nog onvervul, as tot die Israel van die Sionstradisies, wat in die land "geplant" is, veilig en onaantasbaar (vgl. 2 Sam. 7:10).

Wat die slot van Amos betref, geld die volgende: dit verkondig nóg 'n Sionsteologie met statiese inslag, nóg ' $n$ teologie van beweging. Inteendeel, hier is enersyds sprake van gevestig wees (geplant word in die land) en andersyds van 
beweging (vinnige opeenvolging van oestyd en saaityd) en op pad wees (herstel van die vervalle hut van Dawid en die smee van 'n nuwe verhouding tot die nasies). Hierdie benadering van op pad wees sluit goed aan by die profeet Amos se eie veroordeling van die status quo in Israel.

Vir Amos was tempel en paleis die uitdrukking van menslike trots en hoogmoed (Am. 6:8). Tempelbou en die vermeerdering van versterkte stede het in die tyd van Jerobeam II immers uitdrukking gegee aan politieke en staatkundige magsug. Ook die profeet Jeremia maak gebruik van die sinnebeeld van die motief van stad as valse toevlug (vgl. Frick, 1977:223, 225).

Ná die val van die koninkryke van die Tienstammeryk en Juda het 'n verskuiwing van land na stad toe plaasgevind (Weinfeld, 1993:201). Die Israeliete wat uit die ballingskap teruggekeer het, het rondom die tempel en die stad Jerusalem gekonsentreer.

Die stad Jerusalem het veral met die koningskap te doen, in besonder met dié van Dawid.

\section{Die opbou van die vervalle hut van Dawid}

Reimer (1992:229, 233) beperk Amos se onheilsaankondigings tot sosiale en klassegroepe. Die onmag van hierdie groepe is volgens hom die oorsaak van die sterk teologisering by Amos. Dit was die enigste wapen om verandering aan die situasie te probeer aanbring. Hiermee gaan Reimer die problematiek van die boek verby - in elk geval die boek in sy huidige vorm en daarmee ook die problematiek van hierdie artikel.

Amos 9:11 stel vir Israel 'n nuwe, veranderde situasie in vooruitsig en dit raak die koningskap, die verhouding met die ander nasies (9:11-12) en die verhouding met die bodem (9:13-15). Die belofte dat Jahwe "die vervalle hut van Dawid" weer gaan oprig (9:11), rig die fokus weg van die Tienstammeryk af na die tyd van Dawid, voor die rykskeuring. Jahwe gaan 'n nuwe begin maak met Juda en Israel gesamentlik. Die vraag kom op of hier sprake is van 'n herstel van die koninkryk van Dawid soos vanouds.

Talmon (1986:37) sê dat die Bybelskrywers die monargie gesien het as die pilaar van die nasionale bestaan en 'n wesensbelangrike aspek van Israel se historiese ervaring. Daar was 'n diepgewortelde vroom hoop op verlossing en hierdie hoop was gevestig op die monargie en die gesalfde uit die Dawidslyn. Die hoop was nie gefokus op die beeld van 'n unieke Messias nie, maar op 'n dinastie van gesalfde konings. Die verwagtings is ontleen aan die historiese ervaring in die nasionale lewe, veral in die glorieryke verenigde ryk van Dawid en Salomo. In daardie tyd van die verenigde ryk het Israel hulle begeerte verwesenlik om as 'n 
nasie in hulle eie land te woon, geborge en voorspoedig soos nooit in die res van hulle geskiedenis nie. Bybelse hoop vir die toekoms is die gedagtenis aan die verlede, oorgeplant in 'n visie vir die toekoms.

Die terminologie in 9:11-12 herinner inderdaad aan die vroeëre situasie: "Ek stop sy barste toe en bou sy murasies op, Ek herbou hom soos hy in die ou tyd was", en: “... sodat my volk die oorwinnaar sal wees oor wat van Edom oor is". Mays (1974:165, 167) oordeel dan ook dat die stelling in 9:12 nie 'n universele wêreldwye koninkryk in die vooruitsig stel nie, maar 'n herlewing soos wat reeds in Israel se geskiedenis plaasgevind het. Daarom moet hierdie uitspraak volgens hom gesien word in samehang met die belofte in 9:15 dat Israel weer in hulle land geplant sal word. Besit van die land was die doel en voleinding van die ou heilsgeskiedenis.

Die vraag is dus of ons hier te doen het met 'n hertoepassing van die koningstradisie. Volgens 'n ou en diep gewortelde geloof wat baie Judeërs met die hele ou Ooste gedeel het, was die welsyn van die nasie afhanklik van die onderhouding van die sentrale kultus. Die verantwoordelikheid hiervoor het primêr by die koning berus en moeilike tye is toegeskryf aan die verval van tempel en kultus (Hag. 1:2-6; vgl. Hanson, 1987:493).

Hierdeur word die vraag opgeroep of die verwysing na Dawid ook die stad Jerusalem en die tempel op die oog het. Hierteenoor kan 'n mens egter wel vra waarom daar dan verwys word na die vervalle "hut" van Dawid en nie na die "huis" of iets dergelyks nie. Hier word blykbaar eerder 'n "Sionsteologie" afgewys en teruggegryp na die situasie voor die rykskeuring en die gesplete bestaan van die volk van God. Die woord vir hut (סכה) dui iets soos hut, tent, kraal en skerm aan, met ander woorde iets tydeliks, iets vir besondere omstandighede. Die eintlike verblyf is elders of lê nog voor (Gen. 33:17; Lev. 23:34, 42-43; Deut 16:13, 16; 31:10-13; 2 Sam. 11:11; 1 Kon. 20:12, 16; Esra 3:4; Job 27:18; Jes. 1:7-8; Jona 4:5). Ons het hier dus eerder 'n sinspeling op dit waarvan die tydelike hut, tent of skerm 'n vergestalting of simbool is.

In hierdie opsig is die verwysing na 'n tydelike hut, tent of skerm juis iets anders as 'n blote teruggrype na die verlede, anders as by die mitologiese benadering van tydgenootlike nasies. Dawid was maar 'n heenwysing na die eintlike koningskap of koninkryk. Wat kom, is dus eerder 'n korreksie op die koninkryk van Dawid as 'n herhaling daarvan. Preuss (1992:322-323) sê tereg dat God se geskiedenis met Israel waarin sy woord verwerklik word, gerig is op die wêreld, wat Hom moet erken.

Anders as by profete soos Hosea, Miga, Jesaja en Esegiël gaan die verwysing na Dawid dan ook nie daartoe oor om 'n messiaanse verwagting in vooruitsig te stel nie. Die klemtoon val nie op wat 'n komende koning sal doen nie, maar op wat 
God sal doen (9:12: "Hy sal dit doen"; vgl. ook Smith, 1989:282-283). Hy bly getrou en ontfermend ondanks Israel se onverskoonbare ontrou.

Daar moet verder in gedagte gehou word dat die Ou-Testamentiese verwagtings nie bloot ' $\mathrm{n}$ herhaling van die verlede impliseer nie. Vers 12 word dan ook deur die meeste verklaarders so verstaan dat dit nie op blote staatkundige onderwerping van die nasies dui nie, maar op hulle deel hê in die geestelike seëninge vir Israel. In ooreenstemming hiermee gaan vers 13-15 oor tot die beskrywing van 'n toestand van vrugbaarheid en genieting daarvan wat die huidige werklikheid transendeer. Hoewel nog in die gewone tradisionele terminologie, breek hierdie verse deur die huidige werklikheid na 'n meer universele en andersoortige ryk.

God is immers alomteenwoordig (9:1-4), nie landgebonde nie; Hy is die Almagtige wat met skeppersmag oral regeer (9:5-6) en wat sy oogmerk nie alleen met Israel en sy uittog het nie, maar ook met die ander nasies (9:7). Sy besondere verhouding met sy volk beperk geensins sy soewereine vrymag nie. Reg deur die boek word trouens benadruk dat dit vir Jahwe om geregtigheid gaan, en hierdie vereiste geld vir alle volke - universeel (Am. 1-2).

$\mathrm{Na}$ die ballingskap is die funksies wat die koning gehad het, oorgeplaas of gestaak en het die hoëpriester 'n veel belangriker figuur geword (Grabbe, 1992:145). Hanson (1987:499) sê dat daar in die Persiese tyd geen tekens van hoop op ' $n$ herstel van die inheemse Dawidiese koningskap meer is nie. Die Persiese regeerders word geëer as die regeerders wat deur God gekies is, vir wie gebede in die tempel opgestuur word en aan wie gehoorsaamheid verskuldig is in ruil vir die vryheid van geloof in die Tora van Moses (Esra 1:2; 6:4, 22; 7:27-28; 9:9; Neh. 2:8-9, 18). Die beskermhere van die Sadokitiese priesters was nie meer die konings en vorste van die huis van Dawid nie, maar die lede van die imperiale mag van Persië. Hieruit kan ons dus aflei dat die positiewe verwysing na Dawid in die slot van Amos nie ten gunste van 'n datering uit die Persiese tyd getuig nie.

Steinle (1979:86-87 - in aansluiting by Von Rad) sê dat die profete deur die oordeel heen 'n nuwe optrede van God gesien het. Die ou tradisie is nie meer die deurslaggewende nie, want dit is deur die skuld van Israel verbreek. Die profete rig die blik heeltemal op die toekoms, op God wat kom. Hulle hou nog vas aan die oue as gegewe en rig hulle in hulle eskatologiese verwagting geheel en al op die geloof, op die ongrypbare van die teenswoordige en toekomstige optrede van God. Hulle hou nog vas aan die ou beelde, soos Sion, Dawid, uittog, verbond en vestiging in die land en skilder die nuwe dienooreenkomstig. In die latere tyd is die blik meer op iemand uit die Dawidshuis gerig en word dit 'n voorwaarde vir koningwees. 
In die slot van Amos ontbreek die gedagte van 'n messias, maar daar word wel 'n koningskap in vooruitsig gestel wat enersyds aansluit by die vroeëre Dawid, maar andersyds andersoortig is.

\section{5. 'n Buitengewoon voorspoedige tyd en genieting van werksvrug}

Die herstelsituasie in Amos 9:1-15 word beskryf in terme van die gewone bestaan, maar gaan tog ook ver bokant enige bestaanswerklikheid uit. Die beskrywing van die goeie oeste en genieting van die vrug is nie 'n teken van fisisiese verlange na kos nie, maar 'n teken dat Israel onder die seën van Jahwe sal wees, die besondere verbondsverhouding sal geniet en nie die vrugte van die land en hulle besittings aan vyande sal hoef af te staan nie. Dit is dus 'n teëbeeld van die straf wat Amos in 5:11 in vooruitsig gestel het (vgl. ook Gottfriedsen, 1985:159). Soos reeds bo gesien, is Jahwe as die historiese gewer van die land ook die gewer van voorspoed en groei in die natuur, nie die Baäl nie.

Steinle (1979:87-88) wys daarop dat volgens die oud-Oosterse opvatting daar met die aanbreek van iets nuuts ook seën in die natuur verbind is. Kultuur en natuur bereik hulle voleinding. Ons het hier in Amos met iets heeltemal nuuts te doen, nie met die gevolg van 'n ontwikkelingsproses nie, maar met 'n optrede van Jahwe alleen. Hy alleen kan uit die totale vernietiging van die straf, uit die toestand van chaos, iets nuuts tot stand bring (vgl. "Hy sal dit doen" in vers 12; vgl. ook die afsluiting en samevatting van die hele boek met die profetiese formule: "Sê Jahwe jou God").

Gottfriedsen (1985:160) sê dat daar tot in die laaste gedeeltes van die Ou Testament 'n verband gelê word tussen reën en gehoorsaamheid aan Jahwe. So 'n direkte verbandlegging ontbreek egter juis in die slot van Amos, ondanks die sterk beklemtoning daarvan in die res van die boek en vra dus om 'n verklaring.

Soos reeds in verband met die teruggryping na Dawid en die oorwinning oor die nasies (9:11-12) duidelik geword het, is die visie in die slot van Amos wyer as die historiese verlede. Jahwe wat mag het om so 'n wonderlike verandering en uitredding te bewerk, kan ook weer 'n paradystoestand tot stand laat kom. Israel sal weer in 'n land woon wat vir hulle "oorloop van melk en heuning", soos dit elders gestel word (Eks. 3:8, 17; 13:5; 33:3; Lev. 20:24; ens.; vgl. ook Barth, 1991:168). Daar sal weer 'n afgeskaduwing wees van die vredesverhouding waarin Jahwe se verbondsvolk met Hom staan. Dit is die verhouding wat met die skepping vir die mens bedoel was, maar met die sondeval en die verdrywing van die mens uit die paradys verlore gegaan het en tog met die roeping van Abraham en die belofte van ' $n$ land weer in 'n sekere sin herstel is. Dat ploegtyd en oestyd, saaityd en parstyd so vinnig op mekaar volg, dui 'n toestand van oneindige 
voleinding aan. Dit is 'n opheffing van die struktuurorde wat weens die sonde daargestel is (Gen. 3:17-19).

Vanaf vers 14 word die beskrywing weer meer histories (nie-eskatologies) van aard. Jahwe sal die lot van sy volk verander. Hy sal 'n ששוב ששבת bewerkstellig.

Alles in Amos, ook in die slot, benadruk 'n openheid en beweeglikheid, selfs 'n verrassende verloop van sake. Dit staan teenoor 'n geslotenheid en onafwendbaarheid soos in die mitologiese benadering wat ook sy invloed in Israel se kultus laat geld het. Ook in die bestemde, onafwendbare straf van God oor Israel se onverskoonbare onreg en ander sondes, is Hy nie slaafs gebind nie, maar vrymagtig.

\section{Jahwe self bewerk blywende herstel}

Soos bo gesien, het die land tot die sentrale heilsgoedere van Israel behoort. 'n Lang lewe in die land was 'n belofte wat tot gehoorsaamheid moes aanspoor (Eks. 20:12; Deut. 5:16). Deelhê aan die land het ingehou om deel te hê aan die seën van Jahwe (Gen. 27:29; Lev. 26:4-13; Deut. 28:1-14) en aan die vervulling van sy beloftes. In hierdie tekste word gehoorsaamheid wel as voorwaarde gestel, maar Levenson (1985:143-144) keer die verhouding tereg om. Dit is wat die slot van Amos trouens ook doen. Gehoorsaamheid word hier glad nie by name genoem nie, maar blykbaar veronderstel as uitvloeisel van Jahwe se optrede, Hy wat alle inisiatief in die herstel van Israel het (vgl. die bespreking bo). Israel het nie oorspronklik self die land besit nie, maar is daarheen deur Jahwe self gelei. Hulle verbinding met die land is dus nie mitologies, soos by die ander nasies nie, maar histories. Israel se koms na die land is dus iets soos die keersy van die geloof in die verkiesing wat ook histories van aard was en Israel tot aksie en verantwoordelikheid moes aanspoor (vgl. Am. 3:2).

Aangesien Israel nie 'n natuurlike verbinding met die land gehad het nie, maar een van verkiesing en verbond, kon die band met die land ook tot niet gaan. Die band met Jahwe self sou egter nie tot niet gaan nie. Die land het self steeds 'n teken van die trou van Jahwe gebly.

Ballingskap beteken vir die verbondsvolk in 'n sekere sin om sonder God te wees. Tog beteken om sonder land te wees nie sonder meer om sonder God te wees, soos by Israel se tydgenote wat geglo het dat elke land sy eie god het nie. Die God van Israel is oral teenwoordig. Vir Israel beteken ballingskap om sonder God te wees omdat hulle die verkiesing en die verbond verbreek het, met ander woorde hulle verhouding met Jahwe verbreek het. Jahwe het die ballingskap as straf daarop bepaal. Daarmee is Israel in werklikheid nie sonder God nie. Sy teenwoordigheid kan nêrens heen ontvlug word nie (9:1-4). Die ballingskap beteken vir hulle om sonder die gunstige teenwoordigheid van God te wees. 
Nou word Israel weer die konkrete land beloof, soos blyk uit die terminologie "in hulle grond plant" en "hulle sal nie weer uitgeruk word uit die grond wat Ek hulle gegee het (נתתתי) nie" (v. 15). Tog word nie van אריץ gepraat nie, maar van אדמה. Hier word dus aan die bodem in algemene sin gedink eerder as aan die land. Hier is 'n spanning soos tussen die nasionale bedeling in terme waarvan die nuwe situasie geteken word en die universele wat wil deurbreek.

Met die plasing van die land hier so sterk binne die verband van 'n beskrywing in terme van die paradys (v. 13), word aangesluit by die fase waar die konsep van land vir Israel begin het (Gen. 12:1-3). Die land is beloof om iets van die verlore plek en die verlore verhouding met God terug te kry. Dit geld ook vir die mensdom. Israel het wel die plaasvervanger van die mensdom geword, maar laasgenoemde het tog deel aan die uiteindelike doel (Gen. 12:2-3).

Soos by die roeping van Abraham en in teenstelling tot die bouers van Babel, word in Amos nie aangesluit by die konsep van 'n stad nie. Die fokus is op 'n persoon, op Abraham. Die seën vir die nasies sal deur hom bemiddel word en lê dus in 'n persoonlike verhouding (vgl. die afsluiting van Amos: "die Here jou God" as laaste woord).

Land is diensbaar aan hierdie persoonlike verhouding en is histories van aard - in waarde, sowel as in funksie. Dit is nie 'n skeppingsgegewenheid nie en het daarom ook veranderlike waarde en betekenis. Land konstitueer nie die verhouding tussen Jahwe en Israel nie, maar is 'n teken daarvan.

Amos 9:15 gebruik die woord van אדמה, dieselfde woord as in Genesis 3 waar gepraat word van vervloek (3:17); daarheen terugkeer (3:19); weggestuur uit die tuin om die aarde te gaan bewerk waaruit hy geneem is (3:23). Die mens is uitgedryf uit die tuin en die toegang is bewaak (3:24). By die roeping van אדמה Abraham en die belofte van 'n land (Gen. 12:1-3) word nie die term van gebruik nie, maar die term אריץ' (vgl. ook die landbelofte in Gen. 15:7,18-21;

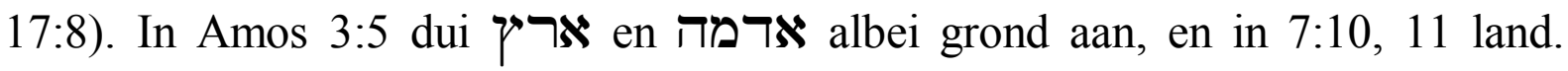
אדמה beteken verder in Amos aarde (3:2), grond (7:10-11) en land/grond (9:15; vgl. ook 7:17). In 7:10-11; 7:17 en 9:15 word dit met ballingskap verbind. Al verwys land hier na die historiese land van die belofte, het die woord tog tegelyk 'n meer kosmologiese en universele betekenis verkry, in ooreenstemming met die eskatologiese aspek van die tekening van voorspoed in vers 13 asook die universele inslag in vers 11-12.

Die terminologie in die belofte dat Jahwe sy volk weer in hulle land sal plant, sluit sterk aan by Jahwe se belofte aan Dawid in 2 Samuel 7. Jahwe beloof daar dat Hy vir Israel 'n plek sal daarstel (vir (10) en Hy praat van "vir "my volk", 
en van "plant" נטע. Dawid antwoord daarop met: "U het 'u volk' Israel vir U gevestig as 'n volk wat vir altyd aan U behoort. En U, Here, het 'hulle God' geword" (v. 24). Amos 9:15 sluit met "sê die Here jou God" en bevestig dus hierdie verbondsbelofte. In 2 Samuel 7 weier Jahwe Dawid se voorgenome tempelbou en gee te kenne dat Hy nie in 'n gebou ingeperk wil wees nie, maar onder en in sy volk wil woon. Dieselfde fokus is in Amos 9:15 op die verhouding tussen Jahwe en sy volk en dit laat dus die feit deurslaan dat Israel 'n koninkryk van priesters was voor en ná hulle 'n meer sekulêre koninkryk was. Land is die plek waar God teenwoordig is en waar Israel sy teenwoordigheid geniet (vgl. ook Brinkman, 1992:26). In hierdie opsig staan die slot van Amos nader aan die priesterlike as aan die Deuteronomistiese benadering (vgl. Noort, 1995:139 vir 'n tipering van laasgenoemde).

Israel het die omgang met God en die hart van godsdiens, naamlik persoonlike verhoudinge, nagelaat. Dit gaan vir die Bybelse godsdiens om die verhouding met 'n God wat nie in plek (tempel, land, Noordryk of Suidryk) of in tyd (feestye of sabbat) ingeperk is nie. Die slot van Amos adem hier die gees van die hele boek: God is vry soos 'n leeu in die velde (1:2), synde Regeerder oor alle volke (1:32:16), Verlosser van sy volk $(2: 9,10)$, deurdat Hy hulle uitkies - vir diens $(3: 2)$. Hy werk veral deur sy onweerstaanbare Woord (3:8). Dit gebeur deur die profete, maar in vrymag - mag wat nie deur hulle of deur die staat, die priester of die volk gemonopoliseer kan word nie (7:10-14). Aangesien hulle dit wel probeer doen, sal Hy sy Woord aan hulle ontneem sodat hulle 'n geestelike dood sal sterf (8:1114). Hy is die Almagtige $(3: 13 ; 4: 13 ; 5: 14-16,27 ; 6: 14 ; 9: 5)$, Onderhouer van die hele skepping, 'n hoedanigheid waarop die ander gode sonder grond aanspraak maak $(4: 7-13 ; 8: 1-3 ; 9: 1-4,5-6)$. Hy is die Skepper van die hemelliggame, wat deur die ander nasies, én deur die ontroue Israel, as gode vereer word $(5: 8,26)$. As persoonlike God is Hy 'n morele God, wat moraliteit en bekering eis, veral by sy volk (vgl. die refrein in 4:6-11; 5:14-15; 18-26). Amos sien die groot moeilikheid van Israel daarin dat hulle die godsdiens verontpersoonlik het en daarom ook geen deernis of gevoel vir reg en geregtigheid teenoor hulle naaste het nie.

Die ware uittog wat sou uitloop op die intog in die beloofde land was nie bedoel as 'n bevoorregting van Israel om hulle eie sin en wil te volg nie (3:9-12), maar om by Hom gebring te word (Eks. 19:4), om sy gebooie te gehoorsaam (Eks. 20) en hulle van hulle sondes te bekeer. Ware uittog is 'n uittog uit die sondige omgewing en uit 'n mens self. Dit is ook die geval by die roeping van Abraham. Al kom die term of oproep tot bekering self nie daar voor nie, word dit tog duidelik geïmpliseer deurdat Abraham daardie land en die huis van sy vader moet verlaat en na die beloofde land toe moet gaan (Gen. 12:1-3). In Klaagliedere 5:21 word uitdruklik gebid dat Jahwe vir Israel tot Hom moet bekeer sodat hulle hulle kan bekeer, of bekeer kan wees. So word die "bestaan van vroeër" herstel. 
Net soos by die roeping van Abraham kom in die slot van Amos die oproep tot bekering nie uitdruklik voor nie, maar is dit implisiet teenwoordig as vrug van God se inisiatief. Die ששוב ששבות is 'n omkeer wat voortvloei uit en rus op God se eie omkeer. Die verrassende van die prediking van die Ou Testament is dat die punt wat agter die verwerping van Israel te staan gekom het, verander is in 'n kommapunt, iets tydeliks en gedeelteliks. God is nie net getrou aan sy verbond שי שוב שבות nie, maar ook aan Homself, sy eie wese (Peels, 1997:13, 28, 30). Die is 'n omkeer na God toe, 'n lotsverandering wat 'n totale verandering, 'n wesensverandering is. Dit is 'n terugkeer vorentoe! Getuie hiervan is die eskatologiese tekening in vers 13, waarin 'n geheel ander situasie as die bloot historiese situasie geskilder word. Dit is in teenstelling met die mitologiese verwagtings en beoefening van die kultus en kom ooreen met die gedagte dat God met sy volk op pad is (vgl. bo). So sal die belofte aan die vaders (Gen. 12:7; ens.) vir goed in vervulling gaan (vgl. Van Leeuwen, 1985:354).

\section{Samevatting en bevinding}

Die slot van die boek Amos fokus op die land. Stad en/of tempel word glad nie eens genoem nie. Hierdie feit word nie verklaar deurdat Samaria, die hoofstad van Israel, tot niet gegaan het (Pfeifer, 1995:134) en die fokus na Jerusalem verskuif het nie, want Jerusalem neem tog wel 'n sentrale plek in die inleiding van die boek in. Die afwesigheid van die idee van stad in die slot begunstig nie 'n ballingskapse of na-ballingskapse datering nie. In elk geval word deur die verbandlegging met land en die verswyging van stad, kant gekies teen enige moontlike mitologiese siening, wat so sterk met die stad verbind was.

Die term vir land veronderstel wel 'n ruimer perspektief as die tradisionele betekenis wat die land vir Israel gehad het. Land word uit die verlede en die eng, eksklusiewe verbinding met die verbondsvolk uitgelig en binne 'n universele raamwerk geplaas waarin die nasies deelhebbers aan die seën van Jahwe is. Hier is ' $n$ universele deurbraak in eskatologiese kleure geskilder, maar tog ook met 'n historiese geworteldheid: die vervalle hut van Dawid word weer opgebou en Israel word weer geplant in hulle land wat Jahwe hulle gegee het.

Deur die vermelding van terugkeer na die land toe, met die verswyging van die stad, word aangesluit by die situasie voor die rykskeuring asook by die belofte van Jahwe aan Dawid by sy voorgenome bou van die tempel. Jahwe het by daardie geleentheid die klem gelê op sy verhouding met mense in teenstelling tot 'n gebou soos die tempel. Die oproep tot die regte verhouding met die naaste, soos in beoefening van geregtigheid wat so sterk deur Amos beklemtoon is, is dus in die slot van Amos slegs oënskynlik afwesig en word in werklikheid geïmpliseer. 
Deur die teruggrype na Dawid word 'n korreksie gemaak op die volk se "Sionsteologie", wat gesentreer het in koning en staatstempel, en waarin die Woord van Jahwe ingeperk, gemonopoliseer en selfs gemitologiseer is. Die fokus in die slot word daarenteen gesentreer in die land van die belofte wat verbind is aan die (ware) verbondsverhouding met Jahwe, soos geïmpliseer in die uitdrukkings "my volk" en "jou God" in die slotwoorde.

Voorts word nog verder teruggegryp na die paradystoestand, in ooreenstemming met die universele aard van die slot waarin ook kosmologiese karaktertrekke begrepe is.

Al sou die voorgaande gegewens nie uitsluitsel gee oor die slot se tyd van ontstaan nie, kan gekonkludeer word dat land in die slot van die boek Amos nie 'n ander plek, waarde en betekenis het as in die res van die boek nie, behalwe 'n sterker universele konnotasie en dat die slot wesenlik dieselfde gees adem as die res van die boek.

\section{Bibliografie}

BARTH, C. 1991. God with us: a theological introduction to the Old Testament. Grand Rapids : Eerdmans.

BRINKMAN, J. 1992. The perception of space in the Old Testament. Kampen : Pharos.

COHN, R.L. 1981. The shape of sacred space: Four Biblical studies. (American Academy of Religion. Studies in Religion. 23.) Atlanta : Scholars Press.

PFEIFER, G. 1995. Die Theologie des Propheten Amos. Frankfurt am Main : Peter Lang.

FRICK, F.S. 1977. The city in ancient Israel. Missoula : Scholars Press.

GOTTFRIEDSEN, Christine. 1985. Die Fruchtbarkeit von Israels Land. (Europeïsche Hochschulschriften. Reihe 23. Theologie. 267.) Frankfurt am Main : Peter Lang.

GRABBE, L.L. 1992. Judaism from Cyrus to Hadrian. London : SCM.

HANSON, P.D. 1987. Israelite religion in the early postexilic period. (In Miller, P.D. et al. Ancient Israelite religion. Philadelphia : Fortress. p. 485-508.)

HELBERG, J.L. 1997. Goddelike onberekenbaarheid en menslike toerekenbaarheid in die boek Amos. In die Skriflig, 31(4):403-419.

HELBERG, J.L. 1998. Land in the Old and New Testament: the dominating personal factor. Koers, 63(3):225-240.

KAISER, O. 1993. Der Gott des Alten Testaments. Theologie des Alten Testaments. I. Göttingen : Vandenhoeck \& Ruprecht.

LEVENSON, J.D. 1985. Sinai and Zion: An entry into the Jewish Bible. Minneapolis : Winston Press.

MAYS, J.L. 1974. Amos. Philadelphia : Westminster. (Old Testament Library.)

METTINGER, T.N.D. 1982. The dethronement of Sabaoth: Studies in the Shem and Kabod theologies. Lund : CWK Gleerup. (Coniectanea Biblica. Old Testament Series. 18.)

NOORT, E. 1995. 'Land' in the Deuteronom(ist)ic tradition. (In Oudtestamentische Studiën, 39. Leiden : Brill. p. 129-144.)

OLIVIER, Hannes, 1996. Spatial awareness; an essential element of historical understanding in Old Testament studies. Old Testament Essays, 9(2):249-260.

PEELS, H.G.L. 1997. De omkeer van God in het Oude Testament. (Apeldoornse Studies, 34.) Apeldoorn : Teologiese Universiteit Apeldoorn. 
PREUSS, H.D. 1991. Theologie des Alten Testaments. I. Stuttgart : Kohlhammer.

PREUSS, H.D. 1992. Theologie des Alten Testaments. 2. Stuttgart : Kohlhammer.

REIMER, H. 1992. Richtet auf das Recht! Studien zur Botschaft des Amos. Stuttgart : Verlag Katholisches Bibelwerk. (Stuttgarter Bibelstudien, 149.)

SMITH, G.V. 1989. Amos. Grand Rapids : Zondervan.

STEINLE, W. 1979. Amos - Prophet in der Stunde der Kriese. Stuttgart : Steinkopf. (Projekte und Modelle zum Dialog mit der jungen Generation, 13.)

TALMON, S. 1984. Midbar. (In Botterweck, G.J., Ringgren, H. \& Fabry, H.-J., reds. Theologisches Wörterbuch zum Alten Testaments, 4. Stuttgart : Kohlhammer. p. 660695.)

TALMON, S. 1986. King, cult and calender in ancient Israel. Jerusalem : Magness Press, Hebrew University.

TSEVAT, M. 1982. jerûsalem / jerusalajim. (In Botterweck, G.J., Ringgren, H., reds. Theologisches Wörterbuch zum Alten Testament. III. Stuttgart : Kohlhammer. p. 930939.)

VAN LEEUWEN, C. 1985. Amos. Nijkerk : Callenbach. (Prediking van het Oude Testament.)

WEINFELD, M. 1993. The promise of the land: The inheritance of the land of Canaan by the Israelites. Berkeley : University of California Press.

ZIMMERLI, W. 1971. Die Weltlichkeit des Alten Testaments. VRO Kleine VandenhoeckReihe. 